\title{
Exploring employer-employee relationship: A psychological contract breach-exit voice and loyalty effect mediated by the dark triad
}

\begin{tabular}{|c|c|}
\hline \multicolumn{2}{|c|}{$\begin{array}{l}\text { Authors: } \\
\text { Uche Mmamel }{ }^{1} \text { (I) } \\
\text { James Abugu }^{2} \\
\text { Leo llechukwu }^{1} \\
\text { Anastasia Ogbo }^{1} \\
\text { Vincent Onodugo }^{1} \text { (D) } \\
\text { Grace Ofoegbu } \\
\text { Henry U. Okwo } \\
\text { He }\end{array}$} \\
\hline \multicolumn{2}{|c|}{$\begin{array}{l}\text { Affiliations: } \\
{ }^{1} \text { Department of Management, } \\
\text { Faculty of Business } \\
\text { Administration, University of } \\
\text { Nigeria, Enugu, Nigeria }\end{array}$} \\
\hline \multicolumn{2}{|c|}{$\begin{array}{l}{ }^{2} \text { Department of Marketing, } \\
\text { Faculty of Business } \\
\text { Administration, University of } \\
\text { Nigeria, Enugu, Nigeria }\end{array}$} \\
\hline \multicolumn{2}{|c|}{$\begin{array}{l}{ }^{3} \text { Department of Accountancy, } \\
\text { Faculty of Business } \\
\text { Administration, University of } \\
\text { Nigeria, Enugu, Nigeria }\end{array}$} \\
\hline \multicolumn{2}{|c|}{$\begin{array}{l}\text { Corresponding author: } \\
\text { Henry Okwo, } \\
\text { henry.okwo.pg81372@unn. } \\
\text { edu.ng }\end{array}$} \\
\hline \multicolumn{2}{|c|}{$\begin{array}{l}\text { Received: } 25 \text { Apr. } 2020 \\
\text { Accepted: } 20 \text { Nov. } 2020 \\
\text { Published: } 31 \text { May } 2021\end{array}$} \\
\hline \multicolumn{2}{|c|}{$\begin{array}{l}\text { How to cite this article: } \\
\text { Mmamel, U., Abugu, J., } \\
\text { llechukwu, L., Ogbo, A., } \\
\text { Onodugo, V., Ofoegbu, G., \& } \\
\text { Okwo, H.U. (2021). Exploring } \\
\text { employer-employee } \\
\text { relationship: A psychological } \\
\text { contract breach-exit voice } \\
\text { and loyalty effect mediated } \\
\text { by the dark triad. South } \\
\text { African Journal of Business } \\
\text { Management, 52(1), a2079. } \\
\text { https://doi.org/10.4102/ } \\
\text { sajbm.v52i1.2079 }\end{array}$} \\
\hline \multicolumn{2}{|l|}{ Read online: } \\
\hline 回展回 & $\begin{array}{l}\text { Scan this QR } \\
\text { code with your } \\
\text { smart phone or } \\
\text { mobile device } \\
\text { to read online. }\end{array}$ \\
\hline
\end{tabular}

Purpose: To understand the underlying employer-employee relationships when there are weak labour laws and high unemployment, we tested a mediation of the 'Dirty Dozen' 12 - items measuring the dark triad (Machiavellianism, psychopathy and narcissism) on the Psychological Contract Breach (PCB) - Exit, Voice and Loyalty (EVL) effect.

Design/methodology/approach: Using 391 respondents comprising the staff of a large financial institution in Nigeria, we formulated the hypotheses to establish direct, indirect and total effects of the variables studied. Constructs diagnostics were performed using confirmatory factor analysis (CFA) for construct validity, composite reliability for internal consistency and Hayes' mediated regression to test the hypotheses.

Findings/results: All direct effects were statistically significant. Narcissism is shown as the non-statistically supported mediator amongst the dark triad, whilst the study showed that the total effect of the multiple mediators worsens loyalty behaviour more than they predict exit behaviour.

Practical Implications: This implies that employers should do better to maintain a healthy work climate in developing climes, as the dominant response to contract breach would not be exit, but rather disloyalty, which would be more disruptive to the organisation than either exit or voice.

Originality/value: Post Coronavirus Disease 2019 (COVID-19) there could be a threat to sustainable work systems. Both employers and employees would have to develop methods to deal with perceived breach from employers and idiosyncratic work behaviour of employees. The contributions of this study would aid sustainable work-related practices, especially within unregulated work environments as present in Africa and other developing nations across the world.

Keywords: contract; exit; voice; loyalty; psychopathy; narcissism; Machiavellianism.

\section{Introduction}

The intention to maintain, or vitiate, the terms of employment is an organisational act that would obviously elicit certain responses from employees within an organisational space. One may go further and argue that the negative act of violating a psychological contract may be predominant amongst organisations in developing countries (Abela \& Debono, 2019; Agarwal \& Bhargava, 2013; Arain, Hameed, \& Farooq, 2012; Bashir \& Nasir, 2013; Chin \& Hung, 2013; Chiu \& Peng, 2008; Delcampo, Rogers, \& Jacobson, 2010; Kasekende, 2017). Developing countries, like any other, have organisations of various sizes and structures that adhere to varying standards based on labour market trends. These organisations in developing countries are more likely to take undue advantage of its employees with the pervasive belief that despite their grievances the employees may have little or no alternative job placements. This somewhat explains the negative influence of the high unemployment conditions amongst densely populated developing countries. It is further expected that the situation would be quite different in countries with low unemployment rates and an entrenched regulatory framework, which would serve to check the excesses of these organisations, whilst mitigating the level of violations in a typical employer-employee relationship. It is also clear that the organisational environment is dynamic, flexible and amenable to sudden contractual adjustments, giving rise to a feeling amongst employees that terms of service stipulated are being violated. These perceived violations thereof are expected to spur certain reactions amongst the employees; reactions that expectedly would in a similar perceptive appear to be negative, dark and

Copyright: @ 2021. The Authors. Licensee: AOSIS. This work is licensed under the Creative Commons Attribution License. 
possibly entropic to the organisation for having violated such terms (Kasekende, 2017; Lapalme, Simard, \& Tremblay, 2011; Orvis, Dudley, \& Cortina, 2010; Rigotti, 2009; Si, Wei, \& Li, 2008; Suazo, 2009; Tufan, De Witte, \& Wendt, 2017; Turnley \& Feldman, 1999; Vantilborgh, 2015).

It is fair to submit that the level of innate morality, emotional intelligence and social consciousness may make a group of employees more predisposed towards reciprocity when they perceive a breach of psychological contract (Gong \& Zhang, 2017). Multiple authors (Atkinson, Matthews, Henderson, \& Spitzmueller, 2018; Bordia, Restubog, \& Tang, 2008; Clinton \& Guest, 2014; Griep, Vantilborgh, \& Jones, 2018; Guo, 2017; Hamel, 2009; Kiazad, Seibert, \& Kraimer, 2014; Kickul \& Lester, 2001) agree that there is a propensity of employees to elicit standard (first-order) negative responses when they perceive a negative work climate, with the theories giving credence to aggravated response of either exit, voice or loyalty. It is also important to state that employers who may disregard their employees' exit as an ultimate response to perceived breach should be aware that the costs of employee turnover is higher compared to that of fulfilling contractual obligations. A salient point to note here is, if distrust in management elicits negative responses, trust should consequently lead to positive organisational responses. So, a supportive supervisor or management would curb the cost of labour turnover, build stability, ensure sustainability and guarantee creativity amongst its staff (Gong \& Zhang, 2017), laying emphasis on the positive states that ultimately benefit the organisation. It is these ultimate responses that are described as Exit, Voice or Loyalty (EVL) states that may exist within an organisation (Hirschman, 1970).

We further add that when these ultimate states are not accomplished, affected employees may become 'dark-hearted' displaying other negative outcomes (Jonason, Strosser, Kroll, Duineveld, \& Baruffi, 2015). Borne out by the same value orientation, employees could likely metamorphose into the ultimate states of either exiting the organisation, voicing out within the organisation or remaining loyal to the goals and dictates spelt out by the organisation. These ultimate states may be predicated as an initial response - of a dubious, reciprocal nature - in trying to payback the organisation for the vitiation meted out to them. These initial outcomes of a psychological contract violation are what we detail as the 'dark triad'. This is so named as it connotes the counter-productive measures in three distinct folds. In no particular order, the first being Machiavellianism - a sense of manipulative exploitation of individuals within the workplace; psychopathy - irrational, anti-social behaviour extended to interpersonal dealings within the workplace and narcissism - an egoistic belief in one's self above all others within the workplace (Gu, Wen, \& Fan, 2017; Jonason et al., 2015; Jonason \& Webster, 2010; Pabian, De Backer, \& Vandebosch, 2015; Paulhus \& Williams, 2002; Rauthmann \& Kolar, 2012; Spain, Harms, \& Lebreton, 2013). Whilst the model for this study does not present an argument singularly on how these outcomes could be predicted by a psychological contract breach (PCB), it rather makes an emphasis that these counter-productive outcomes could over time be extended to the ultimate states of exit - where employees can no longer bear the weight of the violation; voice - where employees may feel that something has to be done to assuage the resultant effect of contractual violations by employers or loyalty - a case of hope rather than despair, with the belief that things could change for the better whilst downplaying whatever disappointment that may have been experienced or perceived.

This discourse on PCB and the diverse responses from employees is not completely new in the organisational psychology and behaviour domain, but whilst most studies have dwelt on how employees responses to such violation could be moderated or interactively explained by certain variables, there is a dearth of work on how these violations and disregard of work terms could lead to certain attitudinal changes or behavioural patterns by employees within the workplace (Agarwal \& Bhargava, 2013; Chin \& Hung, 2013; Griep \& Vantilborgh, 2018; S. Li \& Y. Chen, 2018; Suazo, 2009).

As part of the study's contribution, we controlled for the employment type, taking a keen look at whether an employees' work contract is on a full time or part time basis. We find that most studies that have tried to predict an employee's response from PCB have left out the nature of the employees' work contract, especially for respondents in loosely operated labour markets. It is likely that the unstructured and unstable nature of one's occupation may affect the employees' attitude to either want an exit, or to remain.

Two other major contributions of this study were methodological and theoretical. On the methodological side, it is clear that our study aimed to understand the predictive effect of violating the terms of one's contract within the workplace. Whilst this is a mediated analysis where the possible outcomes of PCB are being considered, most studies in this domain had focused on the interactionism that exists between PCB and other variables in determining certain organisational outcomes, that is emphasising a moderation analysis (Naus, Van Iterson, \& Roe, 2007; Ng, Feldman, \& Butts, 2014; Restubog, Zagenczyk, Bordia, Bordia, \& Chapman, 2015; Turnley \& Feldman, 1999; Zagenczyk, Smallfield, Scott, Galloway, \& Purvis, 2017). And whilst these studies were well suited to query the interaction effects of outcomes such as the contract breach itself, or exit, voice and loyalty (EVL), we delved into the rarity of predicting the ambivalent employees' response arising from a contract breach, which is described in a mediated model. On the theoretical side, the discourse was logical and also predictive, giving sequential support to the methodological model of theorising psychological contract and social exchange as factors defining psychological contract enactment and possible breach; theories of trait activation and affective events defining the prospect of situational cues which could materialise into latent traits in employees and lastly, the 
theory of EVL which defines the ultimate state of employee responses.

Another contribution is related to the tools used to test the hypotheses of this study. Most previous studies have used Baron and Kenny's approach on a conditional hierarchical typology, rather than the simultaneity suggested by Hayes (2018). The concern here is that Hayes has provided an elaborate confutation of the notions of full and partial mediation that continues to be the norm in discussing the results of a mediation model for most works. Also, another limitation that could aid the furtherance of studies like this is one that would have a model where the variables that were used as mediators (dark triad) in this context, could also be simultaneously used as moderators, in a unique moderated-mediation styled approach. We make this suggestion because we feel that a variable like narcissism which does not seem to play a significant indirect role in this study, may well interact with the breach of psychological contract in affecting exit, voice or loyalty. We further suggest the modified use of Model 74 as can be seen in the work by Hayes (2018).

The study consequently has a five-fold theoretical framework that explains the PCB as a predictor, the dark triads as mediators and the EVL states as outcomes; hypotheses development justifying the need to establish a direct, indirect and total effect; materials and methods on scale development, data diagnostics and results, which would lead discussions, contribution to knowledge and theoretical and managerial implications.

\section{Theoretical framework}

The theoretical framework for this study is based on one skeletal frame in a five-fold sequence. We call it a five-fold sequence because it deals with five theories all of which have a bearing on the subject of study and are systematically linked in a logical order. Again, 'logical' because, whilst any two of these may seem similar, their dictates and major assumptions require that we postulate them separate from the others in relation to the study. The theories therefore are divided into three levels, with these levels simply being the three parts of the intended multiple mediation models, as would be seen in the methodology. The first level denotes the theoretical base for the predictor variable - PCB; the second level explains the base for the mediators - dark triad and the third level explains the outcome variables - EVL. The first level tackles both the psychological contract theory of Rousseau and Blau's social exchange theory, the second level deals with Tett and Guterman's trait activation theory and Weiss and Cropanzano's affective event theory, whilst the last in the logical sequence is the Hirschman's EVL theory. It should be noted that these theories are so addressed in the sequence wherewith they relate to the study under consideration. We further apply these theories in a manner that would make them the fulcrum upon which salient points of the study are discussed.
At the first level, the major assumptions of the psychological contract and social exchange theories imply that agreements (contracts) within the workplace are both psychological (meeting of the mind) and social (between parties) exchanges that may be overt or implied, written or verbal, between employers and employees, adherence to which would lead to certain reciprocal outcomes, and neglect or violation would consequently lead to similar mutual outcomes. These theories emphasise the salient undertone of contracts and exchanges that occur within the workplace whilst also emphasising a salient reciprocity that is intricately tied to the furtherance, or otherwise vitiation of the terms of a work contract. Whether the scenario here leads to negative or positive outcomes, the next level of the explained theoretical sequence simply explains the fact that employees would have to respond to the outcome of an agreed contract, whether kept or breached. We should yet add that the disregard for a contract is the antithesis of the theories of psychological contract and that of social exchanges.

At the second level lie the trait activation and affective events theory. These theories espouse the central assumptions to the extent that certain work-related events could affect the psychological and neural disposition of an individual. Whilst the trait activation theory submits that whenever employees perceive specific acts by their organisation to either be favourable or not, these employees develop a disposition or trait that would compensate for such acts by the organisation. Affective events theory on the other hand, focuses on the events that affects an employee at work; predicting the consequent behaviour of such an employee. Both theories describe the construction of workplace reality from a socially latent perspective. This implies that although traits are developed by certain affective events, the exhibitions of such traits thereof are only felt when prompted by situational factors. This explains that an individual could be psychopathic because of how the organisation has acted over time, and such psychopathy could never have been seen at home because the organisation and not the home is the place that nurtured such a trait; the events that prompted this psychopathic behaviour originated from the organisation and not from the home. This is further explained by a major thesis of the trait activation theory that states that behavioural expression of a trait requires arousal of that trait by other trait-related situational cue; these cues being affective events.

Also, in consonance with our study model, we argue that neglect, vitiation, violation and breach of a contract could be the events or cues which become the basis for the development of certain unsavoury traits by employees, usually reciprocal to the magnitude of the violations faced by the employees during the breach of a psychological contract. These unsavoury traits are known in this study as the three dark traits of Machiavellianism, psychopathy and narcissism. It is the overstretched feeling of these traits that may lead to either an employee's exit, protestations (voice) or loyalty. Put differently, it is the exhibition of latent traits borne out of certain affective events that become the 
extended second-order predictors of the ultimate states of exit, voice or loyalty. These ultimate states as explained by Hirschman (1970) are responses that could become the outcome of long-held behavioural adjustments occasioned by shifts and alterations of specific work expectations. This simply implies that when an employee's contract is breached, such an employee can simply choose to remain with the organisation, voice out or leave the organisation. It should be further stated that like the other likely initial outcomes of Machiavellianism, psychopathy and narcissism, the ultimate state outcomes of EVL could be the affected value structures that an individual holds dear.

Third, it should be noted that the EVL model has been expanded to contain 'neglect' and even 'organisational cynicism' (Naus et al., 2007). We do not subscribe to this extension as they do not belong to the basic model, appear to be rather similar to the voice and exit behaviours and have not been adequately given fair consideration by other researchers in the organisational behaviour or organisational psychology domain. We submit that this seems similar because $\mathrm{Ng}$ et al. (2014) made a case for constructive and aggressive voice, where constructive voice is a kind of harmless neglect, and aggressive voice as harmful as neglect, as individuals do not care when organisational processes are badly managed. Also, a strain of exit is rife as it implies the 'intention' to leave, or a tacit withdrawal, which is what neglect signifies. Whilst for the organisation the cynicism aspect of the newly proposed model emphasises on the negative display of attitude from employees with regard to their employer's management of their work terms, we have decided to make use of more fitting responses to an organisational violation of agreed terms, the responses to which are known as the dark triad.

\section{Hypotheses development}

There appear to be an overwhelming convergence amongst researchers that breaches in psychological contracts are perceived by employees when there is lack of reciprocity in the delivery of mutual obligations or promises by their employers (Abela \& Debono, 2019; Agarwal \& Bhargava, 2013; Antonaki \& Trivellas, 2014; Arain et al., 2012; Atkinson et al., 2018; Bordia et al., 2008; Chin \& Hung, 2013; Clinton \& Guest, 2014; Hamel, 2009; Kiazad et al., 2014; S. Li \& Y. Chen, 2018; Ng et al., 2014; Rigotti, 2009; Turnley, Bolino, Lester, \& Bloodgood, 2003; Turnley \& Feldman, 1999). Albeit the fact that a contract breach involves a cognitive assessment of the discrepancy between what is promised and what is delivered, it is erroneous to not equate it to actual violations of physical contracts because they both could provoke employees to renege on the behavioural expectations of their employers ( $\mathrm{Ng}$ et al., 2014). Detrimental to an organisation, there appears to be a consensus as well to ignore the appearance of a contract breach because it could provoke counterproductive reactions and responses from employees (Abela \& Debono, 2019; Bunderson, 2001; Chin \& Hung, 2013; Clinton \& Guest, 2014; Conway \& Briner, 2002; Kiazad et al., 2014;
Orvis et al., 2010; Robinson \& Morrison, 2000; Suazo, 2009; Turnley \& Feldman, 1999; Stoner, Gallagher, \& Stoner, 2011; Zhao, Wayne, Glibkowski, \& Bravo, 2007). The onus therefore is on managers to gauge the cognitive assessment of their workforce regularly.

Based on suggestions from the social exchange theory it can be stated that: an individual in a relationship would reciprocate positively to the other when he (i.e. the other) makes a move to improve the quality of the relationship. We raise an argument that employees would sometimes exceed their job specifications and descriptions with hopes that their employers would do their bit in reciprocation by keeping to their promises and obligations. Where this is the case, there would be a creation of a self-reinforcing cycle whereby no party would want to be considered the villain (Molm, Melamed, \& Whitham, 2013). This could transcend into a climate of stability with regard to commitments, citizenship behaviours, loyalty, engagement, involvement, satisfactions and performance (Abela \& Debono, 2019; Lapalme et al., 2011; Ng et al., 2014; Shore, Coyle-Shapiro, Chen, \& Tetrick, 2009). On the contrary, when contracts are breached, this could result in counterproductive behaviours (Griep et al., 2018; H. Li \& P. Chen, 2018; Suarthana \& Riana, 2016). To this effect, we consider the social exchange theory as advanced by Blau in 1964 to be particularly useful in understanding employees' reactions to $\mathrm{PCB}$.

Employees responses have been captured in Hirschman's (1970) EVL model as an adverse reaction to organisational circumstances that militates against their quest for selfexpression and self-fulfilment (Naus et al., 2007; Si et al., 2008; Vantilborgh, 2015; Witt, 2011). These adverse responses present employees with various options that often times portend grave consequences for their host organisations, because it becomes costlier for such organisations to manage employees with antagonistic tendencies (Hamel, 2009). The 'exit' option expands beyond just physically quitting of the job, but includes the psychological processes of having intentions of quitting (turnover intentions), something that is beyond the control of the organisation. The 'voice' option is pro-social, that is constituting both aggressive and constructive effort of an employee to improve his conditions (Ng et al., 2014). The 'loyalty' option represents employees' propensity to remain optimistic that improvements in the conditions would take place, or render all forms of supports (public or private), whilst engaging in a healthy form of organisational citizenship behaviour (Rusbult, Farrell, Rogers, \& Mainous, 1988). These options either combined or individually have been shown to relate differently with $\mathrm{PCB}$ in previous studies (Arain et al., 2012; Atkinson et al., 2018; Bunderson, 2001; Chiu \& Peng, 2008; Griep et al., 2018; Guo, 2017; Hamel, 2009; Kasekende, 2017; Kiazad et al., 2014; Lapalme et al., 2011; Orvis et al., 2010; Rigotti, 2009; Robinson \& Morrison, 2000; Si et al., 2008; Suarthana \& Riana, 2016; Suazo, 2009; Tufan et al., 2017; Turnley \& Feldman, 1999; Vantilborgh, 2015; Yang \& Chao, 2016; Zagenczyk et al., 2017). Albeit these overwhelming evidences, little can said about 
the effect of PCB on employees responses in the banking industry in Nigeria; an environment where contract breaches are rife (Balogun, Oluyemi, \& Afolabi, 2018; Etodike, Joe-Akunne, \& Obibuba, 2020; Nnadozie, Hilda, \& Ugwu, 2020). Armed with these observations, we therefore postulate the following hypotheses:

H1: Psychological contract breach should have a direct significant effect on the exit, voice and loyalty responses of bank employees.

\section{The mediating role of the dark triad traits}

There is every tendency however that the postulated direct effect hypotheses are more complex than one may envisage. Behaviours and attitudes are basic components of employees, but whilst these are easily displayed and observed, their traits are not and they act as regulators or interventions of their behaviours and attitudes. Traits could be considered positive or negative, depending on their desirableness to the society. In our case, we consider the socially undesirable traits of employees; the 'Dark Triad' (i.e. psychopathy, narcissism and Machiavellianism) and how they intervene on the effects of PCB on employees responses. The psychopathy trait describes the tendency of an employee to be impulsive, apathetic and apprehensive (Jonason et al., 2015; Skeem, Polaschek, Patrick, \& Lilienfeld, 2011; Spain et al., 2013). It explores the antagonistic, superiority and self-promotional side of an employee. The narcissism trait explores the tendency of an employee to engage in selfenhancement that attracts short-term admirations, that are difficult to maintain in the long term because they lack trust and care for others, and end up sometimes in the feeling of disdainforothers(Morf\&Rhodewalt, 2001). Machiavellianism is the tendency of being manipulative, callous and cynical (Becker \& O'Hair, 2007; Zin et al., 2011). These dark triad traits have been confirmed to have implications for counterproductive behaviour (Harms \& Spain, 2015; McLarty, 2015; Rauthmann, 2012; Spain et al., 2013). We also concur that $\mathrm{PCB}$ could prove as an antecedent to the various aspects of the employees' psychopathy, narcissism and Machiavellianism (Lv \& Xu, 2016; Restubog et al., 2015).

Previous studies have shown that 'affective-reactions', that is self-centeredness, callousness, impulsiveness and cynicism are provoked when employees perceive $\mathrm{PCB}$, and these have negative effects on work attitudes like turnover intention, voice and loyalty (Arain et al., 2012; Bordia et al., 2008; Kickul \& Lester, 2001; Zagenczyk et al., 2013, 2017). Similarly, narcissism has been shown in previous studies as well to be higher when the perceptions of PCB increases and this in turn, could indicate negative responses in terms of EVL from employees (Al Aïn, Carré, Fantini-Hauwel, Baudouin, \& Besche-Richard, 2013; Arain et al., 2012; Belschak, Muhammad, \& Den Hartog, 2018; Bordia et al., 2008; Griep et al., 2018; Guo, 2017; Johnson \& O'Leary-Kelly, 2003; Kickul \& Lester, 2001; Lv \& Xu, 2016; Vantilborgh, 2015; Yang \& Chao, 2016; Zagenczyk et al., 2013, 2017; Zhao et al., 2007). Higher levels of Machiavellianism could also stem from breaches in contracts, and this could result in employees' EVL behaviours. With these evidences, we therefore propose that:
$\mathrm{H}_{\mathrm{a}}$ : Psychopathy traits mediate the effects PCB would have on exit, voice and loyalty responses of bank employees.

$\mathrm{H}_{2}$ : Narcissism traits mediate the effects PCB would have on exit, voice and loyalty responses of bank employees.

$\mathrm{H} 2$ : Machiavellianism traits mediate the effects PCB would have on exit, voice and loyalty responses of bank employees.

\section{Material and methods Participants and procedures}

We chose one of the largest and oldest banking institutions in Nigeria, specifically within the South Eastern part of the country, for our study. The instruments were distributed at close of work in different branches across five states, and were to be filled at home and returned at work the next day. This was done through a simple random sampling method. Copies of all respondents who returned their copy the next day were used, whilst copies of those who returned at a later time were collected, but not used for the analysis. We did this to ensure that the respondents were not pressured or compelled to respond to the instrument, whilst clearly stating on the informed consent form that the participation in this survey was voluntary and that respondents could decide not to participate at any time. Moreover, we conducted this survey for 3 months and the first batch was distributed on 12 February 2019, and by 12 May the distribution, collection and collation ended. Of the 391 respondents, those in the youngest age group below 30 years of age were more in number - 98 (25.1\%), whilst those whose jobs were on a contract basis were $238(60.9 \%)$ - greater than those on full-time employment, and $2.3 \%$ of the respondents had served for 18 years within the organisation - being the longest service length of the respondents studied.

\section{Measures}

The measures used in this study were all adapted from previous studies. Because of contextual differences however, slight adjustments were made in some of the scales to suit the context of this study. Apart from the control variables, the outcome, predictor and mediating variables were all designed using the five-point Likert scale ranging from 1 (Strongly Disagree) to 5 (Strongly Agree). The reliability of these scales was accessed through the composite reliability and all scales had their scores above 0.7 . An abridged version: EVL of the EVLN scale, which happened to be the original scale developed by Hirschman in 1970, was adapted from Naus et al.'s (2007) study. The EVL consist of employees' behaviours with regards to EVL. The EVL scales were: Exit Option - this option includes an employee's propensity to quit the job. It measures the extent to which an employee explores possibilities of changing jobs or employers, or even the intention of changing a profession. The loading from this scale indicated that it is reliable in gauging employees' exit option as it showed a composite reliability score of 0.898 . Voice construct - this option accounts for employees' dissatisfaction toward the organisation. It represents the extent to which employees try to work out solutions which 
the organisation might benefit from; come up with suggestions that will prevent dire situations; discuss problems with their supervisors and express their views in a constructive manner. This scale was reliable as well, with a composite reliability score of 0.980 . Loyalty construct this option represents the special attachment that employees have to an organisation. It emphasises the extent to which the employees trust the decision-making processes of the organisation; are optimistic about better times and the employees' willingness to remain confident that situations will be taken care of even without their active contributions. This scale was also reliable with a composite reliability score of 0.968 . The measure of employees perception of PCB was aided by the scale designed by Robinson and Morrison (2000). The scale had five items that measured the extents to which employees perceive that: their employer has fulfilled most of their promises; feel a great deal of anger for the organisation for promises made during hiring, but not being fulfilled; the excellence of employers in keeping up with promises; how much of what have been promised was fulfilled and the extent of employees dismay having kept their part of the bargain. The scale proved reliable with a composite reliability score of 0.955 .

\section{Mediating variables}

This study utilised the concise measure of the dark triad scale known as the 'Dirty Dozen' as developed by Jonason and Webster (2010). The scale comprises three dimensions (psychopathy, narcissism and Machiavellianism), each of which is made up of four items. The psychopathy dimension measures the extent to which employees subtly agree to their lack of remorse, concerns, show of callousness and cynicism. Two items loaded strongly under this scale were: 'I tend to lack remorse' and 'I tend to be callous or insensitive'. The composite reliability for this scale was high at 0.888 . The narcissism dimension measured the extent to which employees agree that they expect their colleagues to admire and pay them attention whilst they seek prestige and expect favours. All the items loaded strongly under the narcissism dimension with a strong composite reliability score of 0.971 . The Machiavellianism dimension measured the extent to which employees agree that they could sometimes be inclined to be manipulative, deceitful and exploitative of their colleagues. All four items of this dimension loaded strongly with a composite reliability score of 0.946 .

\section{Control variables}

In this study, we controlled for the effect of employees age, employment type and employment tenure. These variables have been utilised in previous research (Naus et al., 2007). Employees were presented with five different intervals and asked to select the interval within which their ages fell. The scale was in ranked order, from 1 to 5 , such that 1 was the youngest age bracket, whilst 5 constituted the oldest age bracket. For employment type, employees were place under two categories: contract and permanent staff. A binary coding was assigned to the categories, which was ' 1 ' for 'contract staff', and '2' for 'permanent staff'. Employment tenure measured the length at which employees have been members of the organisation, this was measured in raw values such that the employees were asked to fill in the number of years they had worked with the organisation. The responses for employment tenure were used for analysis after the logarithmic values were computed.

\section{Data analysis}

We analysed the data using the Statistical Package for Social Sciences, v. 21 (SPSS). Also, to estimate the confirmatory factor structure, we used the Analysis of Moment Structures, v. 18 (AMOS) combined with a James Gaskin plugin used to estimate the composite reliability scores. For the test of hypotheses, we used the Hayes approach that implied using a simultaneous entry rather than a conditional entry as suggested by Baron and Kenny. The bootstrapping effect computed here was at 5000. This was done with the aid of an SPSS macro known as PROCESS, v. 3, where Model IV was used to estimate the mediation model, whilst also taking cognizance of the covariates implied in the model.

\section{Construct diagnostics}

Whilst issues of poor fit were critically monitored, the study ensured statistical validity. As in a sequence, we performed a confirmatory factor analysis (CFA) of seven constructs namely $\mathrm{PCB}$, where we used the five items developed by Robinson and Morrison (2000); exit behaviour, voice behaviour and loyalty each having five items as developed by Naus et al. (2007), and the three mediating constructs of Machiavellianism, psychopathy and narcissism (Jonason \& Webster, 2010), also having four items each. All constructs were loaded with standardised estimates above the base value of 0.5 (Schreiber, Nora, Stage, Barlow, \& King, 2006) as can be seen in Figure 1, but two items on the psychopathy construct were ultra-Heywood cases, having a standardised estimate above 1 ; these two items were removed from the structure model. Also, the average variance extracted (AVE) for these constructs were also above the 0.5 threshold (Bagozzi \& Yi, 1988; Hu \& Bentler, 1999; Schreiber et al., 2006), ranging from 0.639 for exit behaviour to 0.908 for voice behaviour. These combined with the composite reliability scores above 0.6, which even ranged from 0.888 for psychopathy to 0.980 for voice behaviour as seen in Table 1 , show that the internal structure of the model fits (Bagozzi \& Yi, 1988). On the overall model fit, the adjusted goodness of fit index (AGFI) was at 0.913, incremental fit index (IFI) at 0.993, comparative fit index (CFI) at 0.994, Tucker-Lewis index (TLI) at 0.993, root mean square residual (RMR) at 0.023 , root mean square error of approximation (RMSEA) AT 0.024 and the chi-square $\left(X^{2}\right)$ to degree of freedom (d.f.) ratio at 1.222; implying a near perfect model fit.

On making a case for the avoidance of common method bias, assuming that we were not able to use different respondents nor did we split the instrument, but collected the data from one respondent group and at the same instance, we checked in two ways. The first 


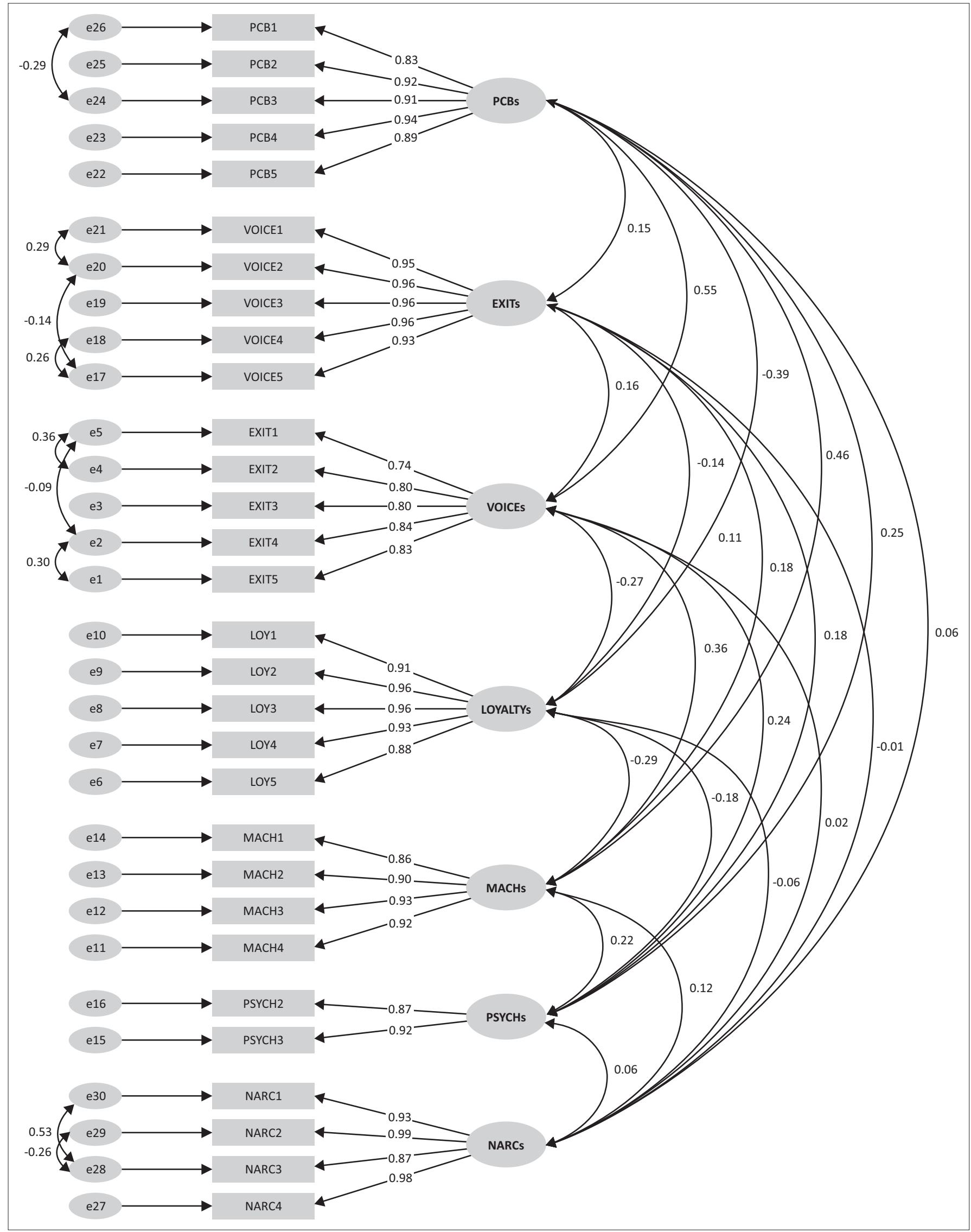

PCB, psychological contract breach; Mach, machiavellianism; psych, psychopathy; narc, narcissism.

FIGURE 1: Confirmatory factor model. 


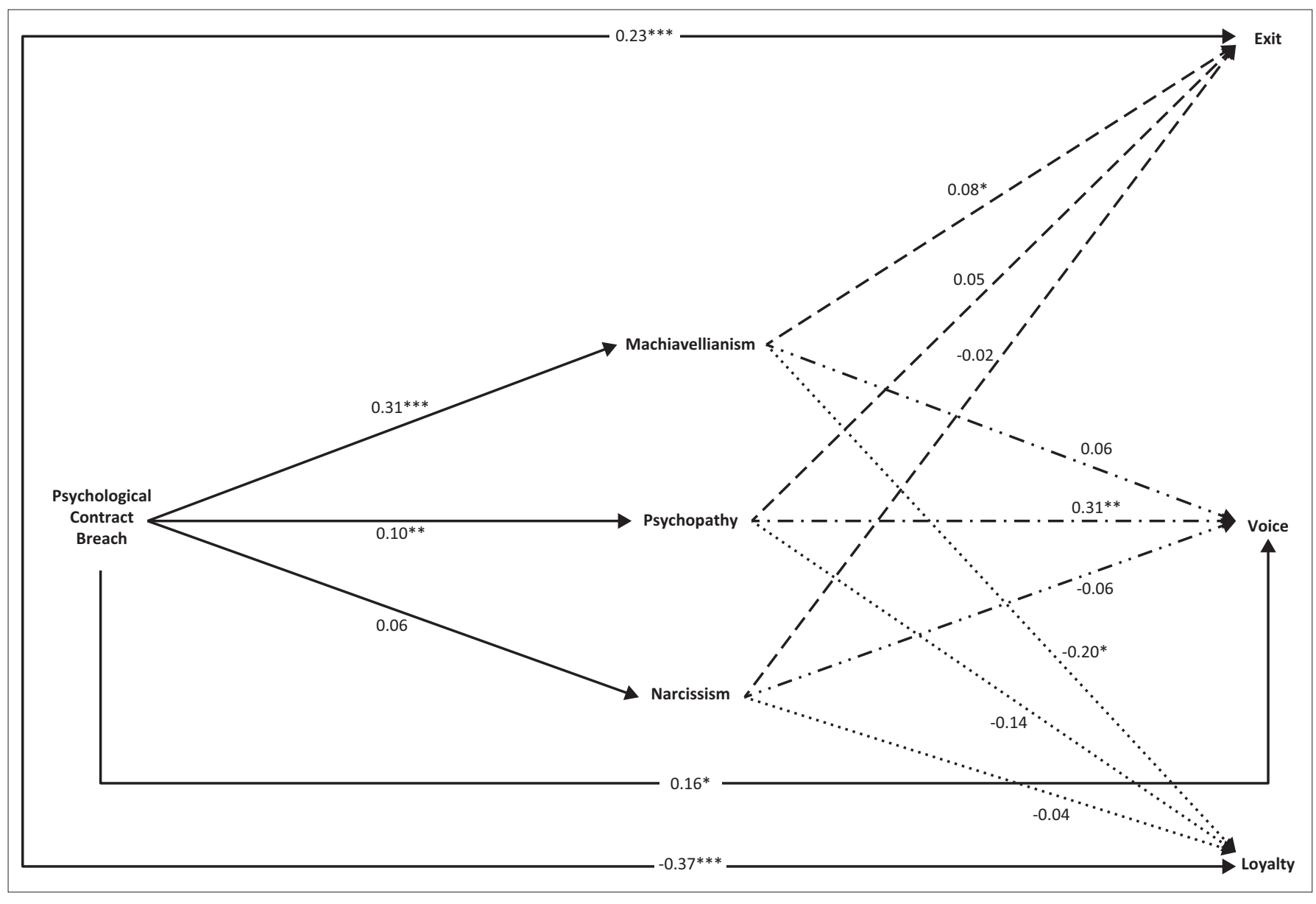

$*, p<0.05 ; * *, p<0.01 ; * * *, p<0.001$.

FIGURE 2: Result structure.

TABLE 1: Inter-item correlation, means, standard deviation and composite reliability.

\begin{tabular}{|c|c|c|c|c|c|c|c|c|c|c|c|c|}
\hline Variable & Means & S.D & РCB & Mach & Psy & Narc & Exit & Voice & Loy & Age group & LogTenure & EmplyType \\
\hline PCB & 17.31 (5 items) & 3.98 & 0.955 & - & - & - & - & - & - & - & - & - \\
\hline Mach & 15.31 (4 items) & 2.89 & $0.436 * *$ & 0.946 & - & - & - & - & - & - & - & - \\
\hline Psy & 7.10 (2 items) & 2.34 & $0.230 * *$ & $0.199 * *$ & 0.888 & - & - & - & - & - & - & - \\
\hline Narc & 11.11 (4 items) & 4.39 & 0.044 & $0.105 *$ & 0.048 & 0.971 & - & - & - & - & - & - \\
\hline Exit & 16.40 (5 items) & 2.37 & $0.516 * *$ & $0.326 * *$ & $0.212^{* *}$ & 0.001 & 0.898 & - & - & - & - & - \\
\hline Voice & 13.41 (5 items) & 5.19 & $0.152 * *$ & $0.110 *$ & $0.177 * *$ & -0.043 & $0.149 * *$ & 0.980 & - & - & - & - \\
\hline Loy & 16.51 (5 items) & 4.86 & $-0.382 * *$ & $-0.272 * *$ & $-0.165 * *$ & -0.064 & $-0.256 * *$ & $-0.142 * *$ & 0.968 & - & - & - \\
\hline Age group & 2.68 (categorical) & 1.34 & $-0.178 * *$ & $-0.128 *$ & $-0.154 * *$ & -0.035 & $-0.354 * *$ & -0.094 & 0.065 & $\mathrm{~N} / \mathrm{A}$ & - & - \\
\hline LogTenure & 0.77 (mean log) & 0.32 & $-0.194 * *$ & $-0.133 * *$ & $-0.134 * *$ & 0.059 & $-0.194 * *$ & $-0.152 * *$ & 0.094 & 0.086 & N/A & - \\
\hline EmplyType & 1.39 (categorical) & 0.49 & $-0.411 * *$ & $-0.171 * *$ & $-0.143 * *$ & 0.000 & $-0.217 * *$ & 0.015 & $0.177 * *$ & -0.010 & $0.129 *$ & N/A \\
\hline
\end{tabular}

$*, p<0.05 ; * *, p<0.01$; composite reliabilities for all the scale factors are presented in bold italics at the table diagonals.

PCB, psychological contract breach; Mach, Machiavellianism; Psy, psychopathy; Narc, narcissism; Loy, loyalty; LogTenure, the logarithmic value for tenure; EmplyType, employment type; N/A, not applicable.

was the Harman's single-factor test as suggested by Craighead, Ketchen, Dunn and Hult (2011), and the second was the common-latent factor method as used by Hu et al. (2018). For Harman's single-factor model, we constrained the model to one fixed extraction, and had a variance at $29 \%$, below the $50 \%$ baseline (Fuller, Simmering, Atinc, Atinc, \& Babin, 2016), implying that no single constructs explained more covariance than it should have (Podsakoff \& Organ, 1986; Tang, Kreiser, Marino, \& Weaver, 2010). Secondly, we constrained the entire model to one factor, performed a CFA and the results showed a terribly poor fit $\left(X^{2}\right.$ to $d f=27.5 ; \mathrm{RMR}=0.237 ; \mathrm{AGFI}=0.232$; $\mathrm{IFI}=0.236 ; \mathrm{TLI}=0.178 ; \mathrm{CFI}=0.235 ; \mathrm{NFI}=0.230$;
RMSEA = 0.261); implying the absence of common method bias (Hu et al., 2018).

\section{Ethical consideration}

The TETFUND Grant approval was vetted by the University of Nigeria Research Ethics Committee and served as the ethical approval for this study.

\section{Results}

The result of the multiple mediation model tested as seen on Figure 2 shows that there was a statistically significant effect of PCB on exit $\left(C_{1}^{1}=0.23 ; p<0.05\right)$; voice $\left(C_{2}^{1}=0.16 ; p<0.05\right)$ 
and loyalty $\left(C_{3}{ }^{1}=-0.37 ; p<0.05\right)$. There was also a direct effect of PCB on Machiavellianism $\left(a_{1}=0.31 ; p<0.05\right)$ and psychopathy $\left(a_{2}=0.10 ; p<0.05\right)$, but not on narcissism $\left(a_{3}=0.06 ; p>0.05\right)$. For the indirect effects, whilst there was a total indirect effect of PCB on exit $\left(\beta_{1}=0.03 ; 0.0039 \leq \mathrm{CI} \leq\right.$ $0.0595)$ and loyalty $\left(\beta_{2}=-0.08 ;-0.14 \leq \mathrm{CI} \leq-0.018\right)$, there was no significant total indirect effect of $\mathrm{PCB}$ on voice when controlling for the three mediators $\left(\beta_{3}=0.04 ;-0.0229 \leq \mathrm{Cl} \leq\right.$ $0.1091)$. For the specific indirect effects, all bootstrapped at $95 \%$ confidence interval at 5000 bootstrapping samples, we found that there was a significant indirect effect of PCB on exit through Machiavellianism $\left(b_{1}^{1}=0.03 ; 0.0010 \leq \mathrm{Cl} \leq\right.$ $0.0542)$, but no indirect significant effect through psychopathy $\left(b_{2}^{1}=0.0050 ;-0.0035 \leq \mathrm{Cl} \leq 0.0167\right)$ and narcissism $\left(b_{3}^{1}=-0.0012\right.$; $-0.0074 \leq \mathrm{CI} \leq 0.0027)$. We found that there was no significant indirect $\mathrm{PCB}$ on voice through Machiavellianism $\left(b^{2}{ }_{1}=0.02\right.$; $-0.0433 \leq \mathrm{Cl} \leq 0.0798)$, an indirect significant effect through psychopathy $\left(b^{2}{ }_{2}=0.0299 ;-0.0052 \leq \mathrm{Cl} \leq 0.0623\right)$ and narcissism $\left(b^{2}{ }_{3}=-0.0041 ;-0.0203 \leq \mathrm{Cl} \leq 0.0060\right)$. We found that there was a significant indirect $\mathrm{PCB}$ on loyalty through Machiavellianism $\left(b^{3}{ }_{1}=-0.06 ;-0.1221 \leq \mathrm{Cl} \leq-0.0034\right)$, but no indirect significant effect through psychopathy $\left(b^{3}{ }_{2}=-0.0138 ;-0.0399 \leq \mathrm{Cl} \leq 0.0061\right)$ and narcissism $\left(b^{3}{ }_{3}=-0.0025 ;-0.0161 \leq \mathrm{Cl} \leq 0.0057\right)$. The total effect also shows a statistical significant effect of PCB on exit $\left(C_{1}=0.26\right.$; $0.2074 \leq \mathrm{CI} \leq 0.3164)$, voice $\left(C_{2}=0.2038 ; 0.0602 \leq \mathrm{CI} \leq 0.3473\right)$

\section{TABLE 2: Effects table.}

\begin{tabular}{lll}
\hline Variables & $\boldsymbol{\beta}$ & $\begin{array}{l}\text { Decision on } \\
\text { significance }\end{array}$ \\
\hline Psychological Contract Breach $\rightarrow$ Exit & 0.23 & Supported \\
Psychological Contract Breach $\rightarrow$ Voice & 0.16 & Supported \\
Psychological Contract Breach $\rightarrow$ Loyalty & -0.37 & Supported \\
Psychological Contract Breach $\rightarrow$ Mach $\rightarrow$ Exit & 0.03 & Supported \\
Psychological Contract Breach $\rightarrow$ Mach $\rightarrow$ Voice & 0.02 & Not supported \\
Psychological Contract Breach $\rightarrow$ Mach $\rightarrow$ Loyalty & -0.06 & Supported \\
Psychological Contract Breach $\rightarrow$ Psychopathy $\rightarrow$ Exit & 0.01 & Not supported \\
Psychological Contract Breach $\rightarrow$ Psychopathy $\rightarrow$ Voice & 0.03 & Supported \\
Psychological Contract Breach $\rightarrow$ Psychopathy $\rightarrow$ Loyalty & -0.01 & Not supported \\
Psychological Contract Breach $\rightarrow$ Narcissism $\rightarrow$ Exit & -0.001 & Not supported \\
Psychological Contract Breach $\rightarrow$ Narcissism $\rightarrow$ Voice & -0.004 & Not supported \\
Psychological Contract Breach $\rightarrow$ Narcissism $\rightarrow$ Loyalty & -0.003 & Not supported \\
\hline
\end{tabular}

Mach, Machiavellianism. and loyalty $\left(C_{3}=-0.4515 ;-0.5791 \leq \mathrm{CI} \leq-0.3239\right)$. The results are as shown on Table 2 and Table 3.

\section{Discussion}

Our study focused on what mediating roles the dark triad variables of Machiavellianism, psychopathy and narcissism could play on the effect of PCB and the variegated employees' response of EVL. Findings showed that the response of EVL were all significantly predicted by breach of employees' contract. It further showed that the effect on exit and voice were positive, whilst that on loyalty was negative. Whilst this result was expected, it was also in consonance with the findings of Chin and Hung (2013), who found a positive significant effect of PCB on turnover intentions (exit), and that of Turnley and Feldman (1999) who also found a positive effect of psychological contract violations on exit (+ve), voice (+ve) and loyalty (-ve). Although in fair contrast, we found a study that showed no statistically significant effect of PCB on employees' voice behaviour, albeit dividing employees' voice behaviour into aggressive and constructive voices $(\mathrm{Ng}$ et al., 2014). We should further add that the total effects of our results show a similitude with our direct effects, but we are also careful in noting that the total effects include the indirect effects also. The expectations that we earlier referred to are premised on sound theoretical grounds and sequential logic as explained in the early part of the study. This part simply implies that when employees' agreements are vitiated, the employee can react either in developing a trait in support of the trait theory, or the employee may just consider an exit, protest or a do-nothing posture in consonance with Hirschman's EVL theoretical model; the results are the same. Also, the fact that the loyalty effect is higher compared to that of exit and voice as a finding of this study, may be explained by the presumption that there are neither job alternatives available to incentivise exit, nor are there proper regulatory labour frameworks to protect the employees during protests, especially within developing countries (Probst \& Ekore, 2010).

On the indirect effects, our results emphasise a stronger effect of PCB through Machiavellianism and psychopathy

TABLE 3: Results from test of hypotheses.

\begin{tabular}{|c|c|c|c|c|c|c|}
\hline Outcomes & Machiavellianism & Psychopathy & Narcissism & Exit & Voice & Loyalty \\
\hline \multicolumn{7}{|l|}{ Controls } \\
\hline Age & -0.11 & $-0.21 *$ & -0.1 & $-0.46 * * *$ & -0.15 & -0.06 \\
\hline Tenure (Log) & -0.44 & -0.62 & 0.99 & -0.53 & $-1.84 *$ & 0.17 \\
\hline Employment type & 0.05 & -0.31 & 0.13 & -0.12 & 1.11 & 0.19 \\
\hline \multicolumn{7}{|l|}{ Predictor } \\
\hline Psychological Contract Breach & $0.31 * * *$ & $0.1 * *$ & 0.06 & $0.23 * * *$ & $0.16^{*}$ & $-0.37 * * *$ \\
\hline \multicolumn{7}{|l|}{ Mediators } \\
\hline Machiavellianism & - & - & - & $0.08^{*}$ & 0.06 & $-0.20 *$ \\
\hline Psychopathy & - & - & - & 0.05 & $0.31 * *$ & -0.14 \\
\hline Narcissism & - & - & - & -0.02 & -0.06 & -0.04 \\
\hline Constant & $10.6 * * *$ & $6.88 * * *$ & $9.33 * * *$ & $12.8 * * *$ & $8.5^{* *}$ & $27.30 * * *$ \\
\hline$R^{2}$ & 0.20 & 0.08 & 0.01 & 0.36 & 0.07 & 0.17 \\
\hline$F(4.386)$ & 23.39 & 8.03 & 0.77 & - & - & - \\
\hline$F(7.383)$ & - & - & - & 30.3 & 4.21 & 10.92 \\
\hline
\end{tabular}

$*, p<0.05 ; * *, p<0.01 ; * * *, p<0.001$. 
than through narcissism, with narcissism being insignificant in all indirect paths. The uniform significance of Machiavellianism and psychopathy may be explained on the basis of both being anti-social dispositions (Bali \& Durand, 2016; McHoskey, Worzel, \& Szyarto, 1998). The fact therefore, that employees would go social or interpersonal, rather than psychological or personal, in response to grievances meted to them at the workplace further lays credence to the situational cues of the trait activation theory, implying that employees who feel that society is the basis of their workplace crisis, would develop traits to hurt such a society. Zagenczyk et al. (2017) support the findings that these traits would hardly be premised on self-glorification, but on interpersonal rancour; one that compensates for the pain of such a breach. Also, our results show that Machiavellianism which is seen as a more manipulative tendency towards others is a much more emphatic mediator than psychopathy and narcissism, The extent to which Machiavellianism serves as the darker outcome compared to the other two is well scripted in organisational psychology(Al Aïn et al., 2013; Birkás, Csathó, Gács, \& Bereczkei, 2015; Gunnthorsdottir, McCabe, \& Smith, 2002; Rauthmann, 2013), whilst also being a likelier personality outcome (Paulhus \& Williams, 2002). Still on the total indirect effect, what still stands out as a non-significant mediator across all outcomes predicted by PCB is narcissism. Narcissism being significantly related to exit behaviour of employees, whilst not significantly related to psychological contract violation is a major finding of Zagenczyk et al. (2017), which is clearly in contrast here, because narcissism is neither correlated with any of exit, voice or loyalty, nor predicts any of them when the other mediators are controlled for.

\section{Theoretical implications}

Numerous theoretical contributions stem from this study's findings. First, the objectives of this study were to examine the direct, indirect and total effects of PCB on employees' responses through the dark triad traits of employees. We built our argument on several theoretical frameworks like the social exchange theory, and the EVL theory. The social exchange theory that explains psychological contracts we predicted as have been implied in other studies would have adverse consequences on employees' reactions, once there are vitiations in contracts. Our results expand its effects to cover bankers in Nigeria who perceive a breach in their psychological contract; this has a direct positive effect on their propensity to exit and/or raise their voices, but has a direct negative effect on their loyalty.

Secondly, this study explored the efficacy of the components of dark triad traits in predicting the effects of PCB on employees EVL directly indirectly. We based our arguments on Tett and Guterman's trait activation theory and Weiss and Cropanzano's affective event theories as well; that the traits (psychopathy, narcissism and Machiavellianism) can be easily provoked by breach in contract and that they could also predict the way employees respond. We discovered that these relationships are more complex than anticipated because PCB does not predict narcissism, nor does narcissism mediate the effects of PCB on employees' responses. By implication, a typical narcissist does not fail to display this trait, whether breach in contract or not, and in the case of an eventual breach, a narcissist's response would always be to exit, raise voice or stay loyal. Therefore, narcissism is not a strong attitudinal response. PCB however has significant effect on both psychopathy and Machiavellianism. By implication, when employees perceive a breach in their contract they are bound to become more impulsive, callous and manipulative. Machiavellianism mediates on the effects of PCB on both exit and loyalty, and not on voice. The import of this is that breach could aggravate the Machiavellian trait, and this could make employees less willing to exit or more willing to remain loyal to the organisation. Psychopathy does not show any of such indirect effects, rather it revealed an indirect effect with voice, meaning that it reduces employees' needs to voice out.

Finally, the total effects of our PCB, dark triad traits and EVL model indicated that PCB leads to exit and voice respectively, through psychopathy, narcissism and Machiavellianism individually, are positive. This indicates that PCB increases a psychopath's propensity to either exit or raise voice; the same implication applies with the narcissist where the propensity to exit or raise voice remains as it was originally; whilst the Machiavellian's propensity to exit or raise voice increases. Psychological contract breach to loyalty, through these traits however, indicated negative total effects. By implications, a psychopath's propensity to remain loyal would decline whence there is a sense that there is a breach in the psychological contract. The same findings apply to the Narcissists and the Machiavellians, whose propensity to stay loyal to the organisation after the perceived breach would dampen.

\section{Managerial implications}

Aggrieved employees are most likely going to remain in the organisation with their grievances, but the fortunes of the organisation would be better if the employees either voice out their pain, or even choose to exit the workplace. Managerial implications of this study centre around powerful actors making efforts towards the understanding that reducing incidents of $\mathrm{PCB}$ actually reduces negative organisational outcomes on one hand, and the fact that employee silence does not imply that the workplace ambience is optimal.

Van Swol, Prahl, Macgeorge and Branch (2019), made it clear that it would be difficult to impose advice on powerful actors and whilst that is true, it is also important that powerful organisational actors understand the covert implications of the principal-agent relationship, especially within a financial firm. Central to breach of contracts is a display of power and a feeling that employees would do little or nothing about it, especially within lax labour regulatory 
environments. Whilst it is true that employees may hardly overtly rebel against the actions of the management, this study shows that a covert rebellion predicated upon counterproductive workplace behaviour would be employees' best response. This implies that the management must value and protect contractual obligations, especially when employees keep their part of the bargain. Management must also understand that employees are their agents sent to directly interact with customers and clients, especially in the financial service sector; employees with provocative dark tendencies, rather than exiting the organisation may take advantage of organisational clients to the detriment of a 'pugnaciously powerful principal'. Management should simply keep their part of the bargain.

Another important management issue is the ability to measure employees' revolt in terms of performance dip rather than voice, or exit behaviour. Management must understand that silence of employees is not always a sign of employees' wellbeing. In fact, employees who are satisfied with their work are more involved and engaged, meaning that they are high in voice behaviour, but employees who are rarely involved in the organisational activities are mostly silent. Because their silence could be attributed to their inability to 'report', or reach-out to the appropriate authorities because of hierarchical issues (Anand, Vidyarthi, \& Rolnicki, 2018; Farh, Hackett, \& Liang, 2007), fear of bullying and retaliation (Rai \& Agarwal, 2018), or simply a lack of better job alternatives; in the event of a possible sack (Breevaart, Lopez Bohle, Pletzer, \& Muñoz Medina, 2020), the management must therefore be able to weigh the mood at the workplace, relying on some form of grapevine and understanding that there is nothing more important to powerless people than powerful people keeping their words. Management should keep its word.

\section{Conclusion}

Employer-employee relationships within developing nations differ from Western nations. Weak labour laws and high unemployment threatens the sanctity of the workplace, causing an asymmetry in expected workplace reciprocity. To explore ways of sustaining this relationship from a behavioural standpoint, we test a mediation of the 'Dirty Dozen' on the PCB-EVL effect. Our study shows that the total effect of the mediations worsens loyalty behaviour more than it may predict exit behaviour. Employers would do better in developing climes, as the dominant response to contract breach would not be exit, but rather disloyalty, which would be more disruptive than exit or voice.

\section{Acknowledgements}

The authors appreciate the efforts of members of the Researchers for Contemporary Issues in the Business Circle. They particularly thank those who are also members of the faculty for their critical efforts towards making this manuscript a reality.

\section{Competing interests}

The authors declare that they have no financial or personal relationships that may have inappropriately influenced them in writing this research article.

\section{Authors' contributions}

U.M., J.A., L.I., A.O., V.O., G.O. and H.U.O. contributed equally to this article.

\section{Funding information}

The authors received support funding from the University of Nigeria TETFUND for Institutional Based Research. The approved research project number is TETFUND/DESS/ UNI/NSUKKA/2018/RP/VOL.1.

\section{Data availability statement}

Data for this study are available on Harvard's dataverse on the link: https:/ /doi.org/10.7910/DVN/EBNMYP.

\section{Disclaimer}

The views and opinions expressed in this article are those of the authors and do not necessarily reflect the official policy or position of any affiliated agency of the authors.

\section{References}

Abela, F., \& Debono, M. (2019). The relationship between psychological contract breach and job-related attitudes within a manufacturing plant. SAGE Open, 9(1) 1-10. https://doi.org/10.1177/2158244018822179

Agarwal, U.A., \& Bhargava, S. (2013). Effects of psychological contract breach on organizational outcomes: Moderating role of tenure and educational levels. Vikalpa, 38(1), 13-25. https://doi.org/10.1177/0256090920130102

Al Aïn, S., Carré, A., Fantini-Hauwel, C., Baudouin, J.Y., \& Besche-Richard, C. (2013). What is the emotional core of the multidimensional Machiavellian personality trait? Frontiers in Psychology, 4(Jul), 1-8. https://doi.org/10.3389/ fpsyg.2013.00454

Anand, S., Vidyarthi, P., \& Rolnicki, S. (2018). Leader-member exchange and organizational citizenship behaviors: Contextual effects of leader power distance and group task interdependence. Leadership Quarterly, 29(4), 489-500. https:// doi.org/10.1016/j.leaqua.2017.11.002

Antonaki, X.-E., \& Trivellas, P. (2014). Psychological contract breach and organizational commitment in the Greek banking sector: The mediation effect of job satisfaction Procedia - Social and Behavioral Sciences, 148, 354-361. https://doi. org/10.1016/j.sbspro.2014.07.053

Arain, G.A., Hameed, I., \& Farooq, O. (2012). Integrating workplace affect with psychological contract breach and employees' attitudes. Global Business and Organizational Excellence, 24(4), 50-62. https://doi.org/10.1002/joe

Atkinson, T.P., Matthews, R.A., Henderson, A.A., \& Spitzmueller, C. (2018). Reactions to psychological contract breaches and organizational citizenship behaviours: An experimental manipulation of severity. Stress and Health, 34(3), 391-402. https://doi.org/10.1002/smi.2798

Bagozzi, R.P., \& Yi, Y. (1988). On the evaluation of structural equation models Journal of the Academy of Marketing Science, 16(1), 74-94. https://doi. org/10.1007/BF02723327

Bali, P., \& Durand, G. (2016). Psychopathy, Machiavellianism and parental behavior: A correlational study modulated by gender. Preprints, October, 1-11. https://doi. org/10.20944/preprints201610.0047.v1

Balogun, A.G., Oluyemi, T.S., \& Afolabi, O.A. (2018). Psychological contract breach and workplace deviance: Does emotional intelligence matter? Journal of Psychology in Africa, 28(1), 8-14. https://doi.org/10.1080/14330237.2018.1426808

Bashir, S., \& Nasir, M. (2013). Breach of psychological contract, organizational cynicism and union commitment: A study of hospitality industry in Pakistan. International Journal of Hospitality Management, 34(1), 61-65. https://doi.org/10.1016/j. ijhm.2013.02.004

Becker, J.A.H., \& O'Hair, H.D. (2007). Machiavellians' motives in organizationa citizenship behavior. Journal of Applied Communication Research, 35(3), 246-267. https://doi.org/10.1080/00909880701434232 
Belschak, F.D., Muhammad, R.S., \& Den Hartog, D.N. (2018). Birds of a feather can butt heads: When Machiavellian employees work with Machiavellian leaders. Journal of Business Ethics, 151(3), 613-626. https://doi.org/10.1007/s10551-016-3251-2

Birkás, B., Csathó, Á., Gács, B., \& Bereczkei, T. (2015). Nothing ventured nothing gained: Strong associations between reward sensitivity and two measures of Machiavellianism. Personality and Individual Differences, 74, 112-115. https:// doi.org/10.1016/j.paid.2014.09.046

Bordia, P., Restubog, S.L.D., \& Tang, R.L. (2008). When employees strike back: Investigating mediating mechanisms between psychological contract breach and workplace deviance. Journal of Applied Psychology, 93(5), 1104-1117. https:// doi.org/10.1037/0021-9010.93.5.1104

Breevaart, K., Lopez Bohle, S., Pletzer, J.L., \& Muñoz Medina, F. (2020). Voice and silence as immediate consequences of job insecurity. Career Development International, 25(2), 204-220. https://doi.org/10.1108/CDI-09-2018-0226

Bunderson, J.S. (2001). How work ideologies shape the psychological contracts of professional employees: Doctors' responses to perceived breach. Journal of Organizational Behavior, 22(7), 717-741. https://doi.org/10.1002/job.112

Chin, P.L., \& Hung, M.L. (2013). Psychological contract breach and turnover intention: The moderating roles of adversity quotient and gender. Social Behavior and Personality, 41(5), 843-860. https://doi.org/10.2224/sbp.2013.41.5.843

Chiu, S.F., \& Peng, J.C. (2008). The relationship between psychological contract breach and employee deviance: The moderating role of hostile attributiona style. Journal of Vocational Behavior, 73(3), 426-433. https://doi.org/10.1016/j. jvb.2008.08.006

Clinton, M.E., \& Guest, D.E. (2014). Psychological contract breach and voluntary turnover: Testing a multiple mediation model. Journal of Occupational and Organizational Psychology, 87(1), 200-207. https://doi.org/10.1111/joop.12033

Conway, N., \& Briner, R.B. (2002). A daily diary study of affective responses to psychological contract breach and exceeded promises. Journal of Organizational Behavior, 23(3), 287-302. https://doi.org/10.1002/job.139

Craighead, C.W., Ketchen, D.J., Dunn, K.S., \& Hult, G.T.M. (2011). Addressing common method variance: Guidelines for survey research on information technology, operations, and supply chain management. IEEE Transactions of Engineering Management, 58(3), 578-588. https://doi.org/10.1109/TEM.2011.2136437

Delcampo, R.G., Rogers, K.M., \& Jacobson, K.J.L. (2010). Psychological contract breach perceived discrimination, and ethnic identification in Hispanic business professionals. Journal of Managerial Issues, 22(2), 220-238. https://doi. org/10.2307/20798906

Etodike, C.N., Joe-Akunne, C.O., \& Obibuba, I.M. (2020). Employee deviance as byproduct of psychological contract: The moderating effects of power distance among employees in insurance companies in Nigeria. Asian Research Journal of Arts \& Social Sciences, 10(4), 44-54. https://doi.org/10.9734/ARJASS/2020/v10i430157

Farh, J.L., Hackett, R.D., \& Liang, J. (2007). Individual-level cultural values as moderators of perceived organizational support-employee outcome relationships in China: Comparing the effects of power distance and traditionality. Academy of Management Journal, 50(3), 715-729. https://doi.org/10.5465/amj.2007. 25530866

Fuller, C.M., Simmering, M.J., Atinc, G., Atinc, Y., \& Babin, B.J. (2016). Common methods variance detection in business research. Journal of Business Research, 69(8), 3192-3198. https://doi.org/10.1016/j.jbusres.2015.12.008

Gong, Z., \& Zhang, N. (2017). Using a feedback environment to improve creative performance: A dynamic affect perspective. Frontiers in Psychology, 8(August), 1-11. https://doi.org/10.3389/fpsyg.2017.01398

Griep, Y., \& Vantilborgh, T. (2018). Let's get cynical about this! Recursive relationships between psychological contract breach and counterproductive work behaviour Journal of Occupational and Organizational Psychology, 91(2), 421-429. https:// doi.org/10.1111/joop.12201

Griep, Y., Vantilborgh, T., \& Jones, S.K. (2018). The relationship between psychological contract breach and counterproductive work behavior in social enterprises: Do paid employees and volunteers differ? Economic and Industrial Democracy, 41(3), 1-19. https://doi.org/10.1177/0143831X17744029

Gu, H., Wen, Z., \& Fan, X. (2017). Structural validity of the Machiavellian personality scale: A bifactor exploratory structural equation modeling approach. Personality and A bifactor exploratory structural equation modeling approach. Personality and
Individual Differences, 105, 116-123. https://doi.org/10.1016/j.paid.2016.09.042

Gunnthorsdottir, A., McCabe, K., \& Smith, V. (2002). Using the Machiavellianism instrument to predict trustworthiness in a bargaining game. Journal of Economic Psychology, 23(1), 49-66. https://doi.org/10.1016/S0167-4870(01)00067-8

Guo, Y. (2017). Effect of psychological contract breach on employee voice behavior: Evidence from China. Social Behavior and Personality, 45(6), 1019-1028. https:// doi.org/10.2224/sbp.6326

Hamel, S.A. (2009). Exit, voice, and sensemaking following psychological contract violations: Women's responses to career advancement barriers. Journal of Business Communication, 46(2), 234-261. https://doi.org/10.1177/0021943608328079

Harms, P.D., \& Spain, S.M. (2015). Beyond the bright side: Dark personality at work. Applied Psychology, 64(1), 15-24. https://doi.org/10.1111/apps.12042

Hayes, A.F. (2018). Introduction to mediation, moderation and conditional process analysis (2nd ed.). New York, NY: Guilford Publishers.

Hirschman, A.O. (1970). Exit, voice, and loyalty: Responses to decline in firms, organization, and states. Cambridge, MA: University Press.

Hu, L., \& Bentler, P.M. (1999). Cutoff criteria for fit indexes in covariance structure analysis: Conventional criteria versus new alternatives. Structural Equation Modeling: A Multidisciplinary Journal, 6(1), 1-55. https://doi. org/10.1080/10705519909540118
Hu, Y., Zhu, L., Zhou, M., Li, J., Maguire, P., Sun, H., \& Wang, D. (2018). Exploring the influence of ethical leadership on voice behavior: How leader-member exchange, psychological safety and psychological empowerment influence employees' willingness to speak out. Frontiers in Psychology, 9, 1-10. https://doi.org/10.3389/ fpsyg.2018.01718

Johnson, J.L., \& O'Leary-Kelly, A.M.O. (2003). The effects of psychological contract breach and organizational cynicism: Not all social exchange violations are created equal. Journal of Organizational Behavior, 24(1), 627-647. https://doi. org/10.1002/job.207

Jonason, P.K., Strosser, G.L., Kroll, C.H., Duineveld, J.J., \& Baruffi, S.A. (2015). Valuing myself over others: The dark triad traits and moral and social values. Personality and Individual Differences, 81, 102-106. https://doi.org/10.1016/j. paid.2014.10.045

Jonason, P.K., \& Webster, G.D. (2010). The dirty dozen: A concise measure of the dark triad. Psychological Assessment, 22(2), 420-432. https://doi.org/10.1037/ a0019265

Kasekende, F. (2017). Psychological contract, engagement and employee discretionary behaviours: Perspectives from Uganda. International Journal of Productivity and Performance Management, 66(7), 896-913. https://doi.org/10.1108/ IJPPM-07-2016-0136

Kiazad, K., Seibert, S.E., \& Kraimer, M.L. (2014). Psychological contract breach and employee innovation: A conservation of resources perspective. Journal of Occupational and Organizational Psychology, 87(3), 535-556. https://doi. org/10.1111/joop.12062

Kickul, J., \& Lester, S.W. (2001). Broken promises: Equity sensitivity as a moderator between psychological contract breach and employee attitudes and behavior Journal of Business and Psychology, 16(2), 191-217. https://doi. org/10.1023/A:1011105132252

Lapalme, M.È., Simard, G., \& Tremblay, M. (2011). The influence of psychological contract breach on temporary workers' commitment and behaviors: A multiple agency perspective. Journal of Business and Psychology, 26(3), 311-324. https:// doi.org/10.1007/s10869-010-9190-5

Li, H., \& Chen, P. (2018). Board gender diversity and firm performance: The moderating role of firm size. Business Ethics: A European Review, 27(4), 294-308. https://doi. org $/ 10.1111 /$ beer.12188

Li, S., \& Chen, Y. (2018). The relationship between psychological contract breach and employees' counterproductive work behaviors: The mediating effect of organizational cynicism and work alienation. Frontiers in Psychology, 9(July), 1-13. https://doi.org/10.3389/fpsyg.2018.01273

Lv, Z., \& Xu, T. (2016). Psychological contract breach, high-performance work system and engagement: The mediated effect of person-organization fit. Internationa Journal of Human Resource Management, 29(7), 1257-1284. https://doi.org/10.1 080/09585192.2016.1194873

McHoskey, J.W., Worzel, W., \& Szyarto, C. (1998). Machiavellianism and psychopathy Journal of Personality and Social Psychology, 74(1), 192-210. https://doi. org/10.1037/0022-3514.74.1.192

McLarty, B.D. (2015). The devil at work: Understanding the dark side of personality and its impact on performance. Louisiana State University and Agricultural and Mechanical College. Retrieved from https://digitalcommons.Isu.edu/gradschool_ dissertations $/ 4063$

Molm, L.D., Melamed, D., \& Whitham, M.M. (2013). Behavioral consequences of embeddedness: Effects of the underlying forms of exchange. Social Psychology Quarterly, 76(1), 73-97. https://doi.org/10.1177/0190272512468284

Morf, C.C., \& Rhodewalt, F. (2001). Expanding the dynamic self-regulatory processing model of narcissim: Research directions for the future. Psychological Inquiry, 12(4), 243-251. https://doi.org/10.1207/S15327965PLI1204_3

Naus, F., Van Iterson, A., \& Roe, R. (2007). Organizational cynicism: Extending the exit, voice, loyalty, and neglect model of employees' responses to adverse conditions in the workplace. Human Relations, 60(5), 683-718. https://doi. org/10.1177/0018726707079198

Ng, T.W.H., Feldman, D.C., \& Butts, M.M. (2014). Psychological contract breaches and employee voice behaviour: The moderating effects of changes in social relationships. European Journal of Work and Organizational Psychology, 23(4), 537-553. https://doi.org/10.1080/1359432X.2013.766394

Nnadozie, N.-I.C., Hilda, O.E., \& Ugwu, K.E. (2020). Psychological contract and employee performance in the construction industry in South East Nigeria. The International Journal of Business \& Management, 8(2), 259-265. https://doi. org/10.24940/theijbm/2020/v8/i2/BM2002-081

Orvis, K.A., Dudley, N.M., \& Cortina, J.M. (2010). Conscientiousness and reactions to psychological contract breach: A longitudinal field study. Journal of Applied Psychology, 93(5), 1183-1193. https://doi. org/10.1037/0021-9010.93.5.1183

Pabian, S., De Backer, C.J.S., \& Vandebosch, H. (2015). Dark triad personality traits and adolescent cyber-aggression. Personality and Individual Differences, 75, 41-46. https://doi.org/10.1016/j.paid.2014.11.015

Paulhus, D.L., \& Williams, K.M. (2002). The dark triad of personality: Narcissism, Machiavellianism, and psychopathy. Journal of Research in Personality, 36(6), 556-563. https://doi.org/10.1016/S0092-6566(02)00505-6

Podsakoff, P.M., \& Organ, D.W. (1986). Self-reports in organizational research Problems and prospects. Journal of Management, 12(4), 531-544. https://doi. org/10.1177/014920638601200408

Probst, T., \& Ekore, J. (2010). An exploratory study of the costs of job insecurity in Nigeria. International Studies of Management and Organization, 40(1), 92-104. https://doi.org/10.2753/IMO0020-8825400106 
Rai, A., \& Agarwal, U.A. (2018). Workplace bullying and employee silence: A moderated mediation model of psychological contract violation and workplace friendship. Personnel Review, 47(1), 226-256. https://doi.org/10.1108/PR-03friendship.

Rauthmann, J.F. (2012). The dark triad and interpersonal perception: Similarities and differences in the social consequences of narcissism, Machiavellianism, and psychopathy. Social Psychological and Personality Science, 3(4), 487-496. https:// psychopathy. Social Psychological and
doi.org/10.1177/1948550611427608

Rauthmann, J.F. (2013). Investigating the MACH-IV with item response theory and proposing the trimmed MACH. Journal of Personality Assessment, 95(4), 388-397. https://doi.org/10.1080/00223891.2012.742905

Rauthmann, J.F., \& Kolar, G.P. (2012). How 'dark' are the dark triad traits? Examining the perceived darkness of narcissism, Machiavellianism, and psychopathy.
Personality and Individual Differences, 53(7), 884-889. https://doi.org/10.1016/j. paid.2012.06.020

Restubog, S.L.D., Zagenczyk, T.J., Bordia, P., Bordia, S., \& Chapman, G.J. (2015). If you wrong us, shall we not revenge? Moderating roles of self-control and perceived aggressive work culture in predicting responses to psychological contract breach. Journal of Management, 41(4), 1132-1154. https://doi. org/10.1177/0149206312443557

Rigotti, T. (2009). Enough is enough? Threshold models for the relationship between psychological contract breach and job-related attitudes. European Journal of Work and Organizational Psychology, 18(4), 442-463. https://doi.org/ $10.1080 / 13594320802402039$

Robinson, S.L., \& Morrison, E.W. (2000). The development of psychological contract breach and violation: A longitudinal study. Journal of Organizational Behavior 21(5), 525-547. https://doi.org/10.1002/1099-1379(200008)21

Rusbult, C.E., Farrell, D., Rogers, G., \& Mainous, A.G., III. (1988). Impact of exchange variables on exit, voice, loyalty, and neglect: An integrative model of responses to declining job satisfaction. The Academy of Management Journal, 31(3), 599-627. https://doi.org/10.2307/256461

Schreiber, J.B., Nora, A., Stage, F.K., Barlow, E.A., \& King, J. (2006). Reporting structural equation modeling and confirmatory factor analysis results: A review. The Journal of Educational Research, 99(6), 323-338. https://doi.org/10.3200/ JOER.99.6.323-338

Shore, L.M., Coyle-Shapiro, J.A., Chen, X., \& Tetrick, L.E. (2009). Social exchange in work settings: Content, process, and mixed models. Management and Organisation Review, 5(3), 289-302. https://doi.org/10.1111/j.1740-8784.2009.00158.x

Si, S.X., Wei, F., \& Li, Y. (2008). The effect of organizational psychological contract violation on managers' exit, voice, loyalty and neglect in the Chinese context. International Journal of Human Resource Management, 19(5), 932-944. https:// doi.org/10.1080/09585190801995849

Skeem, J.L., Polaschek, D.L.L., Patrick, C.J., \& Lilienfeld, S.O. (2011). Psychopathic personality: Bridging the gap between scientific evidence and public policy. Psychological Science, 12(3), 95-162. https://doi.org/10.1177/152910061 Psychologica
1426706

Spain, S.M., Harms, P., \& Lebreton, J.M. (2013). The dark side of personality at work. Journal of Organizational Behavior, 35(1), 41-60. https://doi.org/10.1002/ job.1894

Stoner, J.S., Gallagher, V.C., \& Stoner, C.R. (2011). The interactive effects of emotional family support and perceived supervisor loyalty on the psychological contract breach - turnover relationship. Journal of Managerial Issues, 23(2), 124-143. Retrieved from https://www.jstor.org/stable/23209222
Suarthana, J.H.P., \& Riana, I.G. (2016). The effect of psychological contract breach and workload on intention to leave: Mediating role of job stress. Procedia - Social and Behavioral Sciences, 219, 717-723. https://doi.org/10.1016/j.sbspro.2016.05.056

Suazo, M.M. (2009). The mediating role of psychological contract violation on the relations between psychological contract breach and work-related attitudes and behaviors. Journal of Managerial Psychology, 24(2), 136-160. https://doi. org/10.1108/02683940910928856

Tang, Z., Kreiser, P.M., Marino, L., \& Weaver, K.M. (2010). Exploring proactiveness as a moderator in the process of perceiving industrial munificence: A field study of SMEs in four countries. Journal of Small Business Management, 48(2), 97-115. https://doi.org/10.1111/j.1540-627X.2010.00288.

Tufan, P., De Witte, K., \& Wendt, H.J. (2017). Diversity-related psychological contract breach and employee work behavior: Insights from intergroup emotions theory. International Journal of Human Resource Management, 30(20), 2925-2949. https://doi.org/10.1080/09585192.2017.1350733

Turnley, W.H., Bolino, M.C., Lester, S.W., \& Bloodgood, J.M. (2003). The impact of psychological contract fulfillment on the performance of in-role and organizational citizenship behaviors. Journal of Management, 29(2), 187-206. https://doi. org/10.1177/014920630302900204

Turnley, W.H., \& Feldman, D.C. (1999). The impact of psychological contract violations on exit, voice, loyalty, and neglect. Human Relations, 52(7), 895-922. https://doi. on exit, voice, loyalty, and neglect. Hum
org/10.1177/001872679905200703

Van Swol, L.M., Prahl, A., Macgeorge, E., \& Branch, S. (2019). Imposing advice on powerful people. Communication Reports, 32(3), 173-187. https://doi.org/10.10 80/08934215.2019.1655082

Vantilborgh, T. (2015). Volunteers' reactions to psychological contract fulfillment in terms of exit, voice, loyalty, and neglect behavior. Voluntas, 26(2), 604-628. https://doi.org/10.1007/s11266-014-9441-6

Witt, M.T. (2011). Exit, voice, loyalty revisited: Contours and implications for public administration in dark times. Public Integrity, 13(3), 239-252. https://doi. org/10.2753/PIN1099-9922130304

Yang, W., \& Chao, L. (2016). How psychological contract breach influences organizational identification and organizational citizenship behavior: The mediating role of psychological capital. American Journal of Industrial and Business Management, 6(8), 922-930. https://doi.org/10.4236/ajibm. 2016.68089

Zagenczyk, T.J., Cruz, K.S., Woodard, A.M., Walker, J.C., Few, W.T., Kiazad, K., \& Raja, M. (2013). The moderating effect of Machiavellianism on the psychological contract breach-organizational identification/disidentification relationships. Journal of Business and Psychology, 28(3), 287-299. https://doi.org/10.1007/s10869-012 9278-1

Zagenczyk, T.J., Smallfield, J., Scott, K.L., Galloway, B., \& Purvis, R.L. (2017) The moderating effect of psychological contract violation on the
relationship between narcissism and outcomes: An application of trait relationship between narcissism and outcomes: An application of trait activation theory.

Zhao, H., Wayne, S.J., Glibkowski, B.C., \& Bravo, J. (2007). The impact of psychological contract breach on the work-related outcomes: A meta-analysis. Personnel Psychology, 60(3), 647-680. https://doi.org/10.1111/j.1744-6570. 2007.00087.x

Zin, S.M., Ahmad, N., Ngah, N.E., Ismail, R., Abdullah, I.H.T., \& Ibrahim, N. (2011). Effects of Machiavellianism on ingratiation in organizational settings. Canadian Social Science, 7(2), 183-190. https://doi.org/10.3968/j.css.19236 69720110702.025 